\title{
Electrical Power Supply Consumption in Education Sector and Energy Audit: Case Study of University of Jos
}

\author{
B. I. Gwaivangmin* \\ ${ }^{a}$ Directorate of Physical Facilities University of Jos, Jos, Plateau State, NIGERIA.
}

\begin{abstract}
Electricity supply has been identified as the key constraint to industrialization and economic development in Nigeria. The unbundling of the power sector was aimed at boosting electricity supply, this effort has yielded some appreciable results, but not very significant. As a result of the low power generation and distribution, Nigeria's federal government is working towards solving the prevailing problems of inadequate power in some key sectors by building power generating plants in some of the institutions of learning in the country. This paper looks at the determinants of electrical energy consumption and electrical energy audit, a case study of the University of Jos. The load profiles demand survey, load demand forecast and other important factors were investigated. The result revealed that there is available power of 22-23 hours from the national grid and the balance 1-2 hours of power is supplied by the generating sets, good savings in the cost of diesel and maintenance. An annual excess of 2,199,900 $k W H$ is enjoyed by the university over the national per capita power consumption.
\end{abstract}

Keywords: demand survey, energy audit, energy consumption, load profiles, sustainable energy use

\section{BACKGROUND}

According to [1] education is a very important tool that is used globally to succeed. It is important because it is used to mitigate most of the challenges faced in life. The knowledge that is attained through education helps open doors to a lot of opportunities for future developmental goals in life. The role of the Universities towards human development cannot be over-emphasized; this is why the need for stable power supply on the University Campuses is a task that must be met. Over the years the University of Jos which has a latitude and longitude coordinates 9.896527 , 8.858331 , has suffered serious consequences of erratic power supply which had affected the learning conditions on the Campus. The University had a hug financial burden due to the cost of diesel and maintenance of generators. The learning environment was not conducive to both the Teachers and students in terms of availability of electricity for use and illumination. The advent of the $11 \mathrm{kV}$ dedicated feeder has helped to reduce huge financial burden on the University management and also created a good conducive learning environment to the teachers and students alike.

According to [2] electricity plays a very important role in the socio-economic and technological development of every nation. The electricity demand in Nigeria far outstrips the supply and the

${ }^{*}$ Corresponding author (Tel: +234 (0)802 709 3429)

Email address: bgwaivangmin@gmail.com (B. I. Gwaivangmin) supply is epileptic in nature. The country is faced with acute electricity problems, which is hindering its development notwithstanding the availability of relevant vast natural resources in the country. Adequate power supply is an unavoidable prerequisite to any nation's development; electricity generation; transmission and distribution are capital-intensive activities requiring huge resources of both funds and capacity. In the prevailing circumstances in Nigeria where funds availability is progressively dwindling, creative and innovative solutions are necessary to address the power supply problem.

As reported in [2], despite the power situation in this country, a large percentage of respondents are convinced that power supply and accompanying services provided will improve once the ongoing power sector road map 2010 Act is implemented. Electricity is fundamental and inevitable to our daily living as it lightens our environment, powers our homes, schools, hospitals, offices, businesses, and promotes industrialization. [3, 4] were of the view that insufficient power supply is impeding the development of the Nigerian economy. As such, the need to bridge the gap between demand and supply has become pertinent.

According to [5] observed regional disparities in electricity consumption, access, expenditure and duration of supply also raise important implications for sustainable development, universal access and energy transition objectives. Such disparities, as well as the underlying economic conditions of consumers, should be important considerations in designing the future energy system to 
ensure long term sustainability.

In their submission [6] found out that children study hour reduces with household access to grid electricity, it decreases by 8 percent. Expenditure on electricity significantly decreases children study hour by 12 percent. Electrification decreases the rate at which indoor air pollution reduces by 1.1 percent. Household electricity expenditure increases with reduction in indoor air pollution; it decreases the rate of air pollution by 1.6 percent. Better illumination due from access to modern electricity reduces indoor pollution by 1.2 percent.

According to [7] electricity access is an important factor which speeds up development in most economies of the world. Nigeria's access to electricity has been below economically acceptable level and has not improved in recent times due to some obstacles. These obstacles include; low efficiency and performance, security of fuel sources for power generation, data inadequacy, regulatory barriers, lack of institutional arrangement, poor grid structure, dilapidated transmission and distribution network, low financial investment, lack of policy and project continuity. Ways forward have been presented in order to improve electricity access in Nigeria. The expected improvement may not be immediate but will be a gradual process. To begin to solve this problem in Nigeria, it is important to approach it from a multidimensional perspective. The federal government and the present Minister of Power must understand the gravity of the power crisis and how detrimental it is to the Nigerian and West African economy. The issues must be seen as the number one priority, simply because in the modern world, everything runs on electricity, and to have zero MW per capita simply means to have zero interest in foreign investment and frankly, to operate a dead domestic economy. Therefore all government parastatals and divisions, from defense to trade, to oil and gas, even state and local governments must join hands in carrying out a multi-faceted plan that will rectify the situation in less than a decade.

According to [8] the President said his administration must do everything necessary to increase power generation and distribution from its present status of about 1,500 to 3,500 Megawatts with additional 2000 before the end of the year as a way of halting the ripple effects on the economy. But giving high hopes on the power sector, the President stated that before his government winds up his government will continue to work towards achieving a historic 10,000 Megawatts of electricity and more before 2023.

\subsection{Energy Resources Global Trends}

According to [9] clean coal based generation has been a major source of power in so many countries with coal deposits like Nigeria. The economic growth of countries like the USA, China, South Africa, Australia, India, Germany, to mention just a few, has correlation with their level of generation which is boosted by clean coal based gen- eration. Nigeria with anestimated coal reserve of 2.734 billion tonnes spread across 22 locations cannot continue to solely depend on oil and hydro sources for its power needs in the midst of continuous widening of the gap between Nigeria's electricity demand and supply. Nigeria must key into one or more of these clean coal generation technology options if it is to come out of the dark that it has been for over a century. To reinforce its economic and social development and compete economically with the developed countries of the world, the integration of clean coal power generation in the Nigeria electricity mix is imperative. This will not only guarantee the steady power supply that has eluded it for over a century, but will also ensure security of energy supply and stability in energy prices which are recipes for economic development.

As reported in [10], there is government's desire to ensure stable power supply in the country. Fashola in 2016 stated that the government had signed a Power Purchase Agreement (PPAs) with [11] fourteen different companies to produce $1,125 \mathrm{MW}$ solar power in 9 States and Abuja using God's given sunlight as source of energy. This he said is to demonstrate government's commitment to the development of a robust energy mix, while also achieving its programme of Incremental Power Supply. Achieving sustainable energy development requires rational use of energy resources and technologies, and the development of appropriate policies. There is a huge deficit in supply of energy and this has become a major limitation to growth and quality of life.

The developing nations of Africa are popular locations for the application of renewable energy technology. Nonetheless, largely remain untapped as a consequent of non-conducive business environment; Nigeria faces a number of challenges across its energy triangle. It needs to address an acute energy deficit. At present, power generation is $<5000 \mathrm{MW}$ and apparently the country is not maximizing its human and natural resource potentials. The application of renewable energy technology has the potential to alleviate many of the problems that face Africans every day, especially if done so in a sustainable manner. $[12,13]$ established the fact that despite the privatization of the assets of the unbundled PHCN in 2013, nevertheless, there has not been appreciable improvement in power supply in Nigeria. This is due to numerous challenges facing the investors/management of the new power companies and, indeed, the power system at large. These include the nefarious activities of the oil thieves and pipeline vandals; the lack of effective gas transmission network for thermal power plants, and the problem of dilapidated power equipment. The power companies also face the challenge of raising adequate fund to finance their operations.

According to [14] Nigeria is endowed with oil and natural resources but the country cannot be said to have ever had adequate supply of electricity in the history of its electricity generation. This might get worse, as the country's population in- 
creases and economic development is calling for more demand of energy. The gradual diminishing of fossil fuels and the effort to save the eco-system from global warming has seen nations turning to alternative sources to meet their energy demands. It is therefore, imperative that renewable energy solutions be proffered to cater for Nigeria impending industrialization and its energy crisis which leaves many industries running at high cost and keeps many private homes in blackout. They discussed the potentials of renewable energy as an additional generation source to meet the energy demand of Nigerian populace. Their work focused on the country's energy crisis and how its natural resources can be harnessed to meet the nation's energy demand while reducing global pollution. An analysis of projected energy capacities from the abundant renewable energy resources and how much of these resources are required to be harnessed in the proposed energy mix- to achieve over $60,000 \mathrm{MW}$ of power.

\subsection{Electricity Market Growth}

The electricity market in Nigeria is facing mixed challenges ranging from slow growth in generation capacity, market deregulation process interference by government, electrical transmission lines and distribution equipment vandalism to poor maintenance of existing electrical facilities and corruption. Nigeria should not be different in the trend of global electricity market which focuses on building a cleaner, more diverse and more sustainable energy mix as well as electricity market investment system that is affordable and of proven quality and security. According to [15] possible solutions to the problem of dwindling electrical power supply in Nigeria are: Replacement of aged equipment with new ones (tested and of high quality); Proper and adequate maintenance of electrical power equipment; Stringent and urgent action should be taken by anticorruption agencies to nip the problem of corruption and looting of funds meant for power sector reform in the bud.

According to [16] in addition to the ongoing economic issues plaguing the country, the power issue in the country has also impacted Nigerians hard. Earlier in the year, the National Electrical Regulatory Commission (NERC) decided to increase electricity tariffs without a corresponding improvement in electricity supply. Even citizens without electricity recording meters were presented with ridiculously expensive bills for the power they neither received nor consumed. Surprisingly, regular Nigerians do not face these issues alone as the Distribution Companies (DisCos) and Generation Companies (GenCos) are also stuck in this mess. [11] Observed that the power sector reform in Nigeria has come with both pains and gains, with the former taking the shine off the noble intents of the privatization exercise. Broadly, the challenge with effective and efficient electricity supply in the post-privatized electricity market in Nigeria can be summarised in one word: "shortage". From feedstock availability to electricity units delivered to the end-user, there are severe strains that not only threaten the financial viability of the sector, but also practically repel fresh funding and investment across the value chain. Whilst the persistence of these challenges in a privatised framework does not call into question the validity of the reforms, it points to the need for Nigeria to do more in addressing lingering bottlenecks such as: the sub-optimal utilization of generating capacity; inadequate transmission infrastructure and high distribution losses; and low rates of bills collection. For example, over 3,000 MW of generating capacity is stranded due to gas constraints. Transmission capacity can only wheel $50-60 \%$ of installed capacity, while collection losses range between $40-60 \%$ at the distribution company (Disco) level. [8] pointed out that Nigeria's electric problem is not one dimensional, as over the years many factors have intermingled to impose a multidimensional burden on the country's power generation and distribution potential. In this day and age and with all the natural resources Nigeria is blessed with, it baffles the rational thinking individual why the country is still at the megawatts generation stage, and why it hasn't entered the terawatts realm, or even into the business of selling electricity to other African nations? It appears that the vision of the country's leadership is stuck in the 1970 s mind frame, oblivious of the exponential increase in population and socioeconomy.

According to [17] Considering the size and financial allocation injected into Nigeria's power sector since 1999 and the current electricity generation in the country, which fluctuates between 3,500 MW and 4,748 MW, it is obvious that there is enormous task ahead of the country if it "really" want to join the race, and be part of the league of the top20 leading economies of the world by 2020 as it claimed. It is discovered that corruption is one of the major bottlenecks that plunged the country's power sector into the present situation rather than factors such as population growth. Other factors responsible for the present state of electricity in Nigeria include lack of diversification of energy sources and decentralization of power generation and distribution, poor development and maintenance of the existing energy infrastructure, ineffective private sector participation, deliberate sabotage ("infrastructural terrorism") and negative attitudes of consumers towards offsetting their monthly bills. In order to end the over aged electricity deficit in Nigeria, the country should be willing to harness its enormous resources (both human and material resources) and ensure adequate utilization of both resources. This will help the country to achieve its potentials and compete with the rest of the world. Also, Nigeria is located within the tropics and geographically placed in an advantageous region (best potential sites for wind, solar and hydropower) to generate the needed electricity for its National grid. 
Table 1: University Population.

\begin{tabular}{lll}
\hline Item & Total population & Unit energy demand per capita (kWh) \\
\hline Undergraduate & 36,239 & $4,638,592$ \\
Post Graduate & 5,781 & 739,968 \\
Administrative Staff (Non Academic) & 4,067 & 520,576 \\
Academic Staff & 3,954 & 506112 \\
Total Population & $\mathbf{5 0 , 0 4 1}$ & $\mathbf{6 , 4 0 5 , 2 4 8}$ \\
\hline
\end{tabular}

\subsection{Electrical Energy Audit}

An energy audit identifies where energy is consumed and how much energy is consumed in an existing facility, building or structure. Information gathered from the energy audit can be used to introduce energy conservation measures (ECM) or appropriate energy-saving technologies, such as electronic control systems, in the form of retrofits. Energy audits identify economically justified, cost-saving opportunities that result in significantly lowered electrical, natural gas, steam, water and sewer costs. An energy audit, therefore, is a detailed examination of a facility's energy uses and costs that generates recommendations to reduce those uses and costs by implementing strategies for operational changes. An important part of energy auditing is energy accounting/bill auditing. Energy accounting is a process of collecting, organizing and analyzing energy data. For electricity accounts, usage data normally are tracked and should include metered kilowatt-hour consumption, metered peak demand, billed demand, and rate schedules. Similar data are examined for heating fuel and water/sewer accounts.

All of this information can be obtained by analyzing typical energy bills. Creating energy accounting records and performing bill audits can be done internally without hiring outside consulting firms. Also, while energy audits as a whole will identify excessive energy use and cost-effective conservation projects, bill auditing will assist in identifying errors in utility company bills and beneficial rate and service options. It could provide an excellent opportunity to generate savings without any capital investment. In addition, accurate data from energy accounting/bill auditing is crucial in making an informed energy purchasing decisions in a deregulated energy market such as Nigeria. In the submission of [18] it can be concluded that the most significant indicator in electricity consumption is the Kilo Watt Hour per user (kWh / user). According to [19] the energy audit is one of the first tasks to be performed in the accomplishment of an effective energy cost control program. An energy audit consists of a detailed examination of how a facility uses energy, what the facility pays for that energy, and finally, a recommended program for changes in operating practices or energy-consuming equipment that will cost-effectively save dollars on energy bills. The energy audit is sometimes called an energy survey or an energy analysis, so that it is not hampered with the negative connotation of an audit in the sense of an IRS audit. The energy audit is a positive experience with significant benefits to the business or individual, and the term "audit" should be avoided if it clearly produces a negative image in the mind of a particular business or individual.

\section{MATERIALS AND METHODS}

The case study is the Energy Demand on the $11 \mathrm{kV}$ dedicated feeder which covers Bauchi road Main Campus, Bauchi road Senior Staff Quarters, Students Village Hostel, Naraguta Hostels, Abuja Hostel, Permanent Site Senior Staff Quarters etc. as shown in Fig. 1.

The University of Jos $11 \mathrm{kV}$ dedicated feeder is made up of 14 transformers and about $8.7 \mathrm{Km}$ of distribution line. The main Power transformer is rated 7.5MVA, the other transformers range from $100 \mathrm{kVA}$ to $1000 \mathrm{kVA}$.

\subsection{Power Supply Availability on the $11 \mathrm{KV}$ Feeder}

Before the construction of the $11 \mathrm{kV}$ dedicated feeder, power supply from the then PHCN was $30 \%$ while the remaining $70 \%$ was from the generating sets. With the construction of the $11 \mathrm{kV}$ dedicated feeder, the University power supply is from a 7.5MVA dedicated transformer for use only by the University. The power supply availability within the network is now 22-23 hours on the average and the voltage is $215-240 \mathrm{~V}$ single phase.

\section{RESULTS}

Before the construction of the $11 \mathrm{kV}$ dedicated feeder which was commissioned in June 2013, the University was faced with an inadequate supply of electricity, and dependable on generating sets which have a total capacity of $5,720.4 \mathrm{kWh}$ with a fuel consumption of 7,457 lt/ hr as a major source of power supply, whereas the public electricity supply served as a standby.

The population of the University as at July 2019 is as in Table 1.

\subsection{Analysis}

According to [20] Nigeria's electricity Consumption $\mathrm{kWh}$ per year is $24,000,000,000$ and the average energy per capita (kWh per person) for Nigeria in 2016 was $128 \mathrm{kWh}$, this shows a slight drop from the $144 \mathrm{kWh}$ reported in 2014 by [21]. The global average electricity consumption for households with electricity was roughly $3,500 \mathrm{kWh}$ in 2010. [22] this means Nigeria has a deficit of 3,372 MW, theoretically.

Average power per capita can be calculated as in Eqs. (1) and (2) 


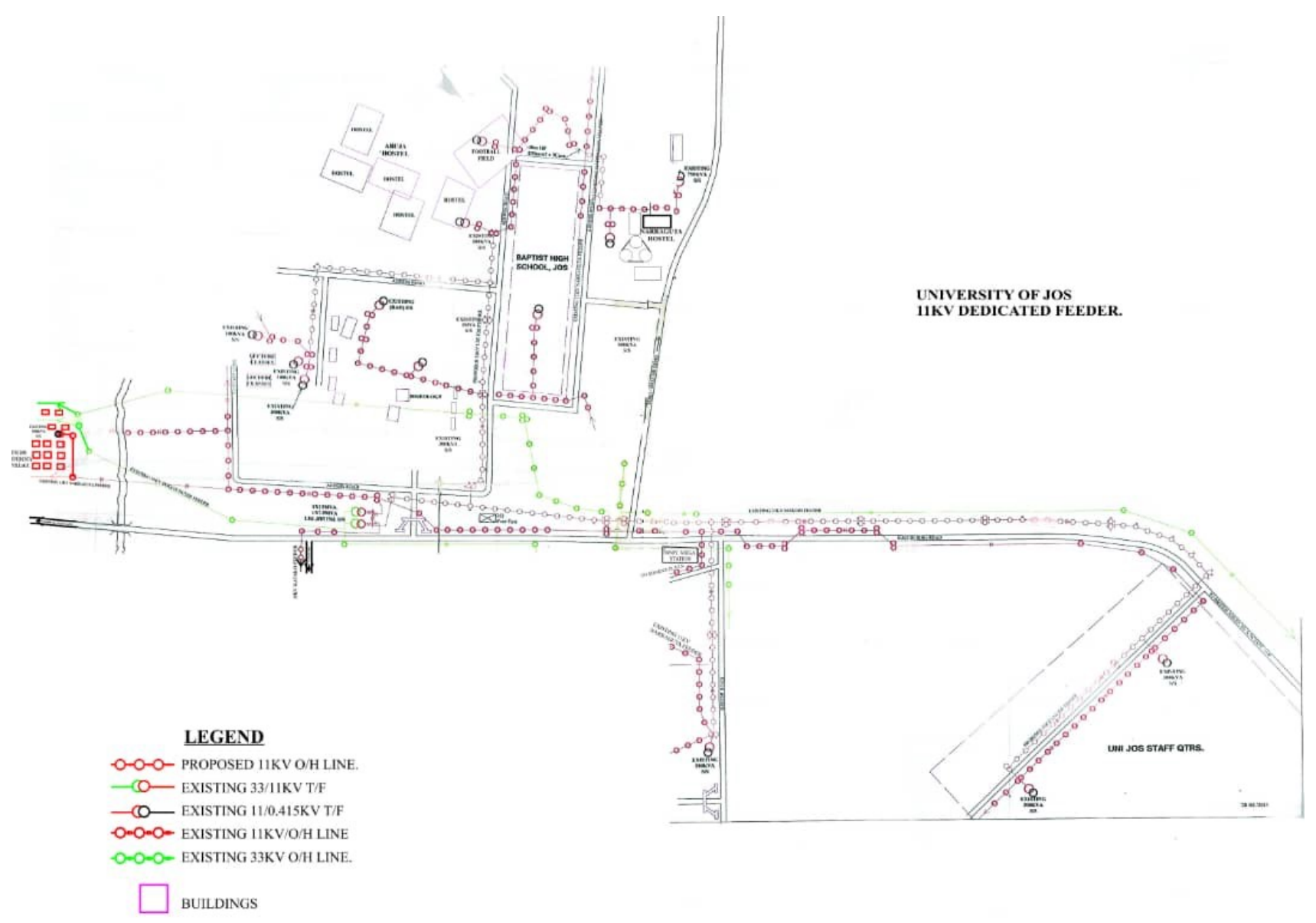

Figure 1: University of Jos $11 \mathrm{kV}$ Dedicated Feeder.

Table 2: Load Profiles.

\begin{tabular}{lll}
\hline 1 & Energy Consumption Profile(daily)-Measured (MWh) & 20.58 \\
2 & Energy Consumption Profile (Peak \& Off Peak) - estimated (MWh) & $1.16-$ Peak \\
& & $0.33-$ Off Peak \\
3 & Energy Consumption Profile(yearly) estimated (MWh) & 5,428 \\
4 & Estimated Energy Demand growth (MWh) & 20 \\
& \multirow{2}{*}{ Jos Electricity Distribution Company Consumption Profile (Monthly) } & $0.2 \%$ \\
\hline
\end{tabular}

Table 3: Demand Survey.

\begin{tabular}{lll}
\hline 1 & Current total energy demand on the $11 \mathrm{kV}$ feeder & 7.2 MW \\
2 & Load Shedding MW & Feeder not Load shaded \\
\hline
\end{tabular}

Table 4: Demand Survey.

\begin{tabular}{lll}
\hline 1 & Estimated energy demand growth & $5 \%$ \\
2 & Suppressed Load (MW) & 2 \\
3 & Not connected load that are considered critical with plans for activation (MW) & 1 \\
4 & Planned expansion load (MW) for new buildings ,hostels e.t.c. & 2 \\
\hline
\end{tabular}


Table 5: Electrical Distribution Network.

\begin{tabular}{lll}
\hline 1 & Installed power distribution capacity of power stations within the University (MW) & 7.2 \\
2 & Power distribution Network Schematics & See Fig. 1 \\
3 & High Level Interconnection substation or transmission substation & 1 \\
4 & Major Power equipment (Transformers, Distribution Network, Protection and Control e.t.c) & 12 No, \\
& & $11 / 0.415 \mathrm{kV}$ \\
\hline
\end{tabular}

Table 6: Diesel Generators.

\begin{tabular}{lll}
\hline 1 & Average Daily Operational Hours & 2 \\
2 & Average Monthly Fuel Consumption Data (Ltrs) & $37,518.52 \mathrm{Ltrs}$ \\
3 & Average Monthly Amount spent on fuel (N) & $10,654.067$ \\
4 & Installed Capacity in MW & 6,215 \\
5 & Total Capacity of Self Generation in MW & 6,423 \\
6 & Total Number of Generators & 35 \\
\hline
\end{tabular}

Table 7: Monthly Average Electricity Consumption per Point Load Transformer (kWH) for a period of 12 Months. (May 2019 -April 2020).

\begin{tabular}{lll}
\hline 1 & Medical Sciences & 401,520 \\
2 & Natural Science & 236,739 \\
3 & Naraguta Female Hostel (ZION) & 152,306 \\
4 & Central Library & 106,985 \\
5 & Senior Staff Quarters, Permanent Site & 989,860 \\
6 & Students Village Hostel & 783,990 \\
7 & Abuja Male Hostel & 670,220 \\
8 & Abuja Female Hostel & 773,332 \\
9 & Faculty of Education Sub-Station. & 143,893 \\
10 & Lecture theatre (Skye Bank) & 54,656 \\
11 & Naraguta & 9,207 \\
12 & Naraguta Male & 460,309 \\
13 & Geological Centre & 75,483 \\
14 & Naraguta Security Light & 3,448 \\
& Total & $\mathbf{4 , 7 6 1 , 9 4 8}$ \\
\hline
\end{tabular}

Table 8: Average recorded Power Consumption of the $11 \mathrm{kV}$ Dedicated Feeder over a period of 12 Months.

Average load of three phase on the feeder

$98 \mathrm{~A}$

Table 9: Load demand for Dedicated feeder load locations.

\begin{tabular}{|c|c|c|c|c|c|c|c|c|c|c|c|c|}
\hline & May-19 & June & July & August & Sept & October & Nov & Dec & Jan-20 & Feb & March & April \\
\hline Med.Sc & 36,980 & 30,820 & 41,840 & 33,500 & 38,020 & 44,710 & 33,800 & 25,000 & 21,050 & 20,710 & 35,000 & 40,090 \\
\hline Nat.Sc & 30,753 & 1,111 & 17,123 & 28,201 & 31,458 & 35,771 & 28,420 & 18,646 & 14,742 & 1,747 & 27,000 & 1,767 \\
\hline Zion & 11,572 & 13,121 & 22,083 & 12,008 & 16,647 & 18,973 & 17,100 & 21,689 & 5,503 & 5,984 & 15,000 & 14,275 \\
\hline Library & 9,644 & 4,500 & 13,127 & 10,618 & 14,924 & 21,953 & 15,380 & 2,060 & 2,014 & 2,015 & 2,675 & 2,198 \\
\hline P.SQtrs & 98,430 & 88,897 & 89,120 & 78,239 & 83,674 & 99,712 & 87,706 & 79,560 & 69,234 & 75,623 & 83,123 & 56,987 \\
\hline Village.H & 51,030 & 69,510 & 101,720 & 98,990 & 86,200 & 89,920 & 93,780 & 22,590 & 17,050 & 19,960 & 80,020 & 55,820 \\
\hline Abj.M.Hos & 62,624 & 46,620 & 96,890 & 81,850 & 98,150 & 68,730 & 57,940 & 18,050 & 9,600 & 12,060 & 65,720 & 63,580 \\
\hline Abj.F.Hos & 369,518 & 72,638 & 95,543 & 79,556 & 86,913 & 88,169 & 82,463 & 21,459 & 14,069 & 17,472 & 80,041 & 72,385 \\
\hline Fac.Ed.1 & 4,601 & 4,670 & 4,961 & 5,536 & 5,543 & 5,769 & 5,002 & 1,058 & 1,791 & 703 & 2,029 & 3,313 \\
\hline Skye Bank & 5,234 & 4,824 & 6,207 & 4,933 & 4,728 & 6,541 & 4,258 & 2,951 & 2,802 & 2,427 & 2,891 & 3,756 \\
\hline Naraguta & 6,604 & 1,450 & 1,276 & 1,455 & 1,411 & 1,67 & 1,789 & 1,001 & 21 & 196 & 298 & 850 \\
\hline Naragut.M & 77,526 & 30,080 & 93,700 & 49,622 & 34,304 & 35,047 & 29,580 & 13,584 & 4,656 & 7,710 & 44,917 & 39,583 \\
\hline Geo.Cntr & 6,650 & 6,442 & 6,439 & 5,774 & 9,214 & 9,686 & 8,965 & 2,830 & 2,527 & 3,137 & 4,761 & 9,087 \\
\hline Nargt.St.L & 238 & 298 & 238 & 238 & 238 & 238 & 238 & 4,000 & 714 & 238 & 238 & 200 \\
\hline
\end{tabular}




\section{Load Demands}

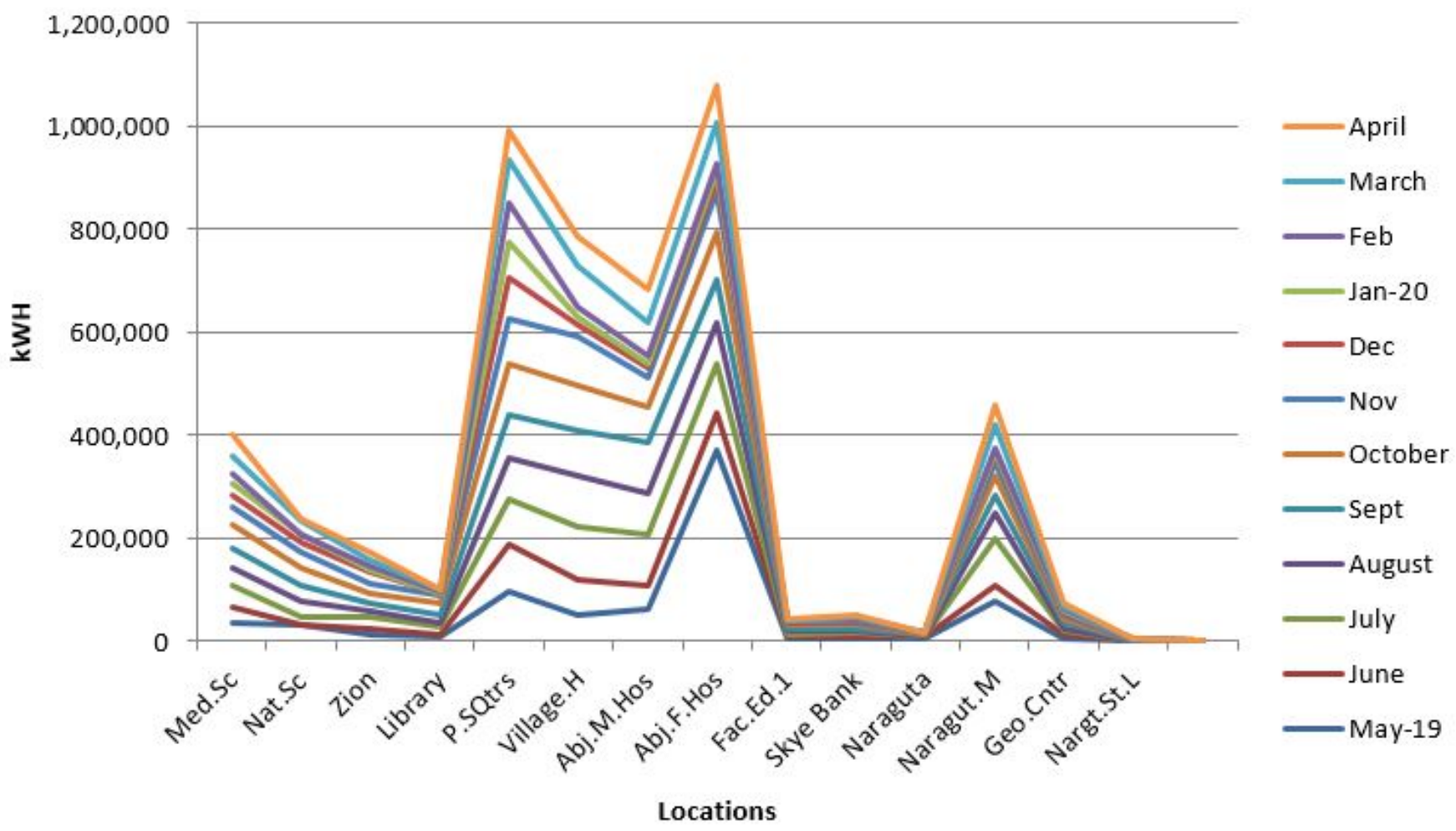

Figure 2: Graph of Table 9.

Electric power per capita [in watt-hour] =

Total population electricity consumption $(\mathrm{kWh} / \mathrm{yr})$

$\times \frac{1000}{\frac{(365.25 \times 24)}{\text { population }}}$

Electric power per capita [in watt-hour] =

Total population electricity consumption (in $\mathrm{kWh} / \mathrm{yr}$ )

$\times \frac{0.114077116}{\text { population }}$

Where:

Watt

$1 \mathrm{kWh} / \mathrm{yr}=1,000 \mathrm{Wh} /(365.25 \times 24) \mathrm{h}=0.11408$

\subsection{Load Profile}

Table 2 Shows the JEDC consumption profile as at July 2019 estimated as 543 MWh monthly. The consumption for May 2019 - April 2020 has an average of 397 MWh monthly, a difference of $146 \mathrm{MWh}$ over a period of 1year. This shows an energy growth of $26.89 \%$. This is represented in Table 9 and Fig. 2.

The energy demand growth was projected as $0.2 \%$ load profile (Table 2 ) and $5 \%$ Load and demand forecast (Table 4).
Plan for expansion according to Table 4 is $2 \mathrm{MW}$ while proposal for re-activation of critical loads not connected is $1 \mathrm{MW}$ and suppressed load $2 \mathrm{MW}$. This gives a total of 5 MW.

\subsection{Comparison with Annual per Capita Consumption in Nigeria}

With a population of 50,041, the total power required annually at the University of Jos is 50,041 $\times 128=6,405,208 \mathrm{kWh}$.

With a monthly average of $396,829 \mathrm{kWh}$ the University is expected to consume, 4,761,948 $\mathrm{kWh}$,

It is estimated that Just about $40 \%$ of the population stay within the $11 \mathrm{kV}$ dedicated feeder; $50,041 \times 0.4=20,016$.

Which means a power consumption of $20,016 \times$ $128=2,562,048 \mathrm{kWH}$

This shows that the University has 2,199,900 $\mathrm{kWh}$ in excess of the national per capita power consumption. From Table 8; Average load of dedicated feeder $=98 \mathrm{~A}$

Power of dedicated feeder P:

$$
\begin{aligned}
P & =\sqrt{3} \times 11 \mathrm{kV} \times I \times 0.8 \\
& =1.732 \times 11,000 \times 98 \times 0.8 \\
& =1,493,676.8 \mathrm{~kW} \\
& =1.49 \mathrm{MW}
\end{aligned}
$$

The total power generated from the generating sets is $5,720.4 \mathrm{~kW}$ 
This shows that the generating sets runs at an excess power of approximately 4.0 MW.

\section{CONCLUSION}

The power supply situation in Nigeria has not improved despite all the attempts by government to ensure that the unbundling process is successful. The plan to build power generating stations in some of the educational institution is a welcome development, but proper studies must be carried out before investment. From the data in the electrical consumption and electrical energy audit template for 2019 , it can be seen that there is a wide margin between the energy demand growth projection and the actual figures after one year. This calls for proper load analysis of the network to ensure that the load demand forecast meet the desired goal since commencement of projects sometimes take up to 5 years. With available power of 22-23 hours from the national grid, the generating sets run on an average of $1 \mathrm{hr}$ per day, hence a savings in the cost of diesel and maintenance (Spare parts).

From the electrical consumption and electrical energy audit, a solar power plant is a preferred type of plant to be considered, with an economic capacity of $3.66 \mathrm{MW}$, approximately $4 \mathrm{MW}$.

The University as a result of having a dedicated feeder is expected to enjoy an annual excess of $2,199,900 \mathrm{kWh}$, over the national per capita power consumption. This goes to show that the present power situation in the University is good and no investment for an independent power generation is required at least for now.

The average recorded power consumption from the $11 \mathrm{kV}$ dedicated feeder is $1.49 \mathrm{MW}$, while the generating sets produce a power of approximately $5.720 .4 \mathrm{MW}$ an excess of 4.23 MW from the actual power consumption. This amounts to wastages in terms of power, diesel, maintenance and human resources.

\section{RECOMMENDATION}

Though power supply availability is appreciable, there is the need for proper energy audit to improve the proper use of power. Energy Management strategies should be employed to ensure that electricity consumption is controlled so that payments for power consumed will not be a burden to the university, especially with the continuous increase in energy tarrif.

\section{References}

[1] A. Abdulghani. (2014) The importance of education. [Online]. Available: www, researchgate.net

[2] A. Sambo, M. Gaji, and I. Zarma. (2010) Electricity generation and the present challenges in the nigerian power sector. [Online]. Available: http://www.researchgate.net/publication/228399732

[3] T. Olugbenga, A. Abdul-Ganiyu, and D. Phillips, "The Current and Future Challenges of Electricity Market in Nigeria in the face of Deregulation Process," African Journal of Engineering Research, vol. 1, no. 2, pp. 33$39,2013$.

[4] V. Okolobah and Z. Ismail, "On the Issues, Challenges and Prospects of Electrical Power Sector in Nigeria," International Journal of Economy, Management and Social Sciences, vol. 2, no. 6, pp. 410-418, 2013.
[5] K. Olaniyan, B. McLellan, S. Ogata, and K. Tezuka, "Estimating Residential Electricity Consumption in Nigeria to Support Energy Transitions," Sustainability, vol. 10, no. 5, pp. 1-22, 2018.

[6] I. Olanrele, B. Abiola, and I. Olatunde, D .and Joseph, "The Impact of Access to Electricity on Education and Health Sectors in Nigeria's Rural Communities," Journal of Entrepreneurship and Sustainability Issues, 2020

[7] N. Emodi and S. Yusuf, "Improving Electricity Access in Nigeria: Obstacles and the Way Forward," International Journal of Energy Economics and Policy, vol. 5, no. 1 , pp. 335-351, 2015 .

[8] I. Ifedobi. (2016) Practical Solutions to Nigeria's Electricity Crisis. [Online]. Available: http://www.vanguardngr.com/2016/07/practicalsolutions-nigerias-electricity-crisis $/ .2016$

[9] A. Essien and E. Igweonu, "Coal Based Generation: A Solution to Nigeria Electricity Problem," International Archive of Applied Sciences and Technology, vol. 5, no. 1, pp. 74-80, 2014.

[10] L. Nwabughiogu. (2016) Power situation in nigerian no longer laughing matter. [Online]. Available: http: //www.vanguardngr.com/2016/03/power-situationnigeria-no-longer-laughing-matter-buhari/2016

[11] U. Capital, "Nigerian power sector report - is there light at the end of the tunnel?" The Intelligent Choice, 2017.

[12] N. Saifuddin, S. Bello, S. Fatihah, and K. Vigna, "Improving Electricity Supply in Nigeria-Potential for Renewable Energy from Biomass," International Journal of Applied Engineering Research, vol. 2, no. 14, pp. 8322-8339, 2016.

[13] A. Njoku, "An Examination of the Challenges of Power Supply in Nigeria in Post-Privatisation Era," International Journal of Applied Engineering Research, vol. 3, no. $1,2016$.

[14] T. Olaoye, T. Ajilore, K. Akinluwade, F. Omole, and A. Adetunji, "Energy Crisis in Nigeria: Need for Renewable Energy Mix," American Journal of Electrical and Electronic Engineering, vol. 4, no. 1, pp. 1-8, 2016.

[15] S. Fabiyi, A. Abdulmalik, and H. Tiamiu, "Dwindling Electrical Power Supply in Nigeria: Causes and Possible Solutions," International Journal of Science and Research, vol. 5, no. 5, pp. 635-639, 2013.

[16] F. Agbugah, "Current state of power supply in nigeria," Business Venture, 2016.

[17] A. Naibbi and Y. Tukur, "Ensuring Optimal Electricity Generation and Supply: The Paradox of Nigeria's Situation," International Research Journal of Environmental Sciences and Studies, vol. 2, no. 1, pp. 1-14, 2017.

[18] L. Pepplow, R. Betin, and T. Pereira, "Forecasting the electricity consumption in a higher education institution," Brazilian Archives of Biology and Technology, vol. 62, no. spe: e19190004, 2019.

[19] T. W.C. and S. Doty, Energy Management Handbook, 6th ed., ser. GA 30047. India: The Fairmont Press, 2006.

[20] Wikipedia. (2016) List of countries by electricity consumption. [Online]. Available: https://en.wikipedia.org/wiki/List_of_countries_ by_electricity consumption\#cite note- 2

[21] W. Bank. (2014) World bank collection of development indicators. [Online]. Available: http://data.worldbank org/indicator/eg.use.elec.kh.pc

[22] L. Wilson. (2017) Average household electricity use around the world. shrink that foot print. [Online]. Available: http://shrinkthatfootprint. com/average-household-electricity-consumption\# yFZM5wstdSLpdeGH.99.2017 